\title{
Reasons for customers reluctance to use electronic payments - A study in Ho Chi Minh City
}

\author{
Le Thi Thanh Xuan ${ }^{1 *}$, Tran Tien Khoa ${ }^{2}$, Nguyen Thi Kha ${ }^{1}$ \\ ${ }^{1}$ Hochiminh City University of Technology - VNUHCM, Vietnam \\ ${ }^{2}$ International University - VNUHCM, Vietnam \\ *Corresponding author: 1ttxuan@hcmut.edu.vn
}

ARTICLE INFO

DOI: $10.46223 / \mathrm{HCMCOUJS.}$ econ.en.9.2.155.2019

Received: February $26^{\text {th }}, 2019$

Revised: April 19 ${ }^{\text {th }}, 2019$

Accepted: August 15 ${ }^{\text {th }}, 2019$

Keywords:

e-payment, hard laddering interview, hierarchical value map (HVM), means- end chain (MEC) theory, resistance
This study aims to investigate reasons why customers are reluctant to use e-payment and how these reasons explain their impacted values, with the following research objectives: (1) to identify characteristics of electronic payment generating the resistance of customers to this E-payment; (2) to explore the connections between those characteristics and values of individuals through the consequences of these characteristics; (3) to propose suggestions for service providers and financial institutes to develop appropriate strategic plans to motivate epayment in Vietnam. To address these research objectives, the means-end chain (MEC) theory is employed with hard laddering interviews as data collection methods. Then, the collected data are analyzed by the Association Pattern Technique (APT) and used to build the Hierarchical Value Map (HVM). The HVM indicates five main reasons which bar customers from using e-payment: (1) lack of information about e-payment and its benefits, (2) security vulnerabilities in online payment systems, (3) unavailability of legal laws to protect epayment users, (4) unpopularity of e-payment, and (5) transaction fees and no discount for e-payment. The Value map also revealed that Safety is the most crucial value explaining why most customers are unwilling to use e-payment. Besides, the respondents also care about the Economy and the Convenience of e-payment. From these findings, the study offers some suggestions for banks and service providers to increase the popularity of e-payments.

\section{Introduction}

Vietnam is considered a high potential market for e-payment. According to the World Bank data, Vietnam has had a growth rate of 6.46 percent per year since 2000, one of the highest rates in the world. The majority of its population is under 35 accounting for 57\% (Loi, 2017), and they are the most tech-savvy group contributing to more than $50 \%$ of internet users in 
Vietnam and high e-commerce increase of average $22 \%$ growth year on year (E-commerce revenue went up 22\% in 2017). Vietnam is a developing country with high internet use rate of 52 percent, which is ranked $15^{\text {th }}$ in the globe (VietnamBriefing, 2017; VietNamNews, 2017). The rate is increasing at 9 percent per year. The percentage of smartphone and mobile Internet users is also high. The number of mobile subscriptions has increased to 131.9 million with smartphone ownership reaching 72 percent and 53 percent in urban and rural areas, respectively. Vietnamese people use mobile Internet for many activities, such as surfing social networks. However, they are not familiar with electronic payments and Vietnam is still a cash dominated economy with 90 percent of all transactions conducted in cash (VietnamBriefing, 2017).

The Vietnamese government has developed a plan to reduce cash transactions and improved electronic payment methods to support government initiatives to become a cashless economy by 2020 (Fintechnews, 2017). With a plan to equip all supermarkets, shopping malls, stores, and distributors with facilities to accept credit cards, it is expected that cash payment would account for less than $10 \%$ of the total market transactions. In addition, various utility providers such as electricity, water, telecommunication, internet, etc., are accepting electronic payment methods and trying to make e-payment easier and more popular to Vietnamese people. However, these efforts are not strong enough to motivate the Vietnamese to accept electronic payment.

According to Ram and Sheth (1989), there are many reasons for customer resistance to changes. This resistance is normal and customers will not adapt to changes unless such reasons are addressed thoroughly. Therefore, to motivate Vietnamese customers to adopt e-payment, it is necessary to investigate why they are resistant to electronic payment. Accordingly, this paper aims (1) to identify characteristics of e-payment generating customer resistance to its use; (2) to explore the connections between those characteristics and values of individuals through the consequences of these characteristics; (3) to propose suggestions for service providers and financial institutes to develop appropriate strategic plans to motivate e-payment in Vietnam.

\section{Literature review}

\section{Innovation Resistance Theory (IRT)}

The meaning of Innovation Resistance (IR) is the resistance by the consumers due to possible changes in current satisfactory state or difference from their idea of innovation (Ram \& Sheth, 1989). According to this theory, consumers do not easily accept innovations. Two types of resistance to innovation adoption are functional and psychological barriers.

\section{Means-end chain theory}

Means-end chain (MEC) theory was designed by psychologist Tolman (1932) and economist Abbott (1955) (as cited inter Hofstede, Audenaert, Steenkamp, \& Wedel, 1998), who recognized that consumers choose a product not for its own sake but for the value and benefits brought about by that product. According to Reynolds and Gutman (1988), consumers select a product or service when its attributes can help them achieve the desired values or benefits from using such a product.

In the MEC theory, consumers relate to products by a hierarchical cognitive structure 
of three interlinked levels: product attributes, consequences of product use and personal values (Grunert \& Grunert, 1995; Hofstede et al., 1998; Reynolds \& Gutman, 1988). Three concepts form the content of consumer knowledge, whereas the structure is created from the linkages among them. The linkage will then help to explain consumer decision making to translate product or service characteristics or attributes and consequences of use into personal selfrelevant values as the desired ends. Attributes are tangible and intangible characteristics of a product (Reynolds \& Gutman, 1988). Consequences are defined as any result (physiological or psychological) accruing directly and indirectly to the consumer (sooner or later) from their behavior (Gutman, 1982). It reflects the benefits or consequences related to product attributes. Values are the intangible and desired-ends value of consumers which represent their most fundamental needs.

\section{Laddering interview}

Reynolds and Gutman (1988) stated that laddering is the most widely applied technique to reveal means-end structures. Two approaches for laddering interview include soft and hard laddering interviews. The soft-laddering interview allows freedom in customer answers and their natural flow of speech. The hard-laddering interview, on the other hand, allows less freedom in consumer answers and navigate consumers to follow questions set up in advance and let them choose the best answer from a defined list.

\section{Previous studies on E-payment}

In his study conducted in Iran, Yassaman (2009) used MEC theory to explore why Iran customers do not use Internet banking (IB). The findings showed 10 attributes (A) from such reasons including (1) No computer/No Internet connection, (2) Internet Environment, (3) IB account creation procedure, (4) IB payment procedure, (5) Enter billing and card information, (6) Lack of a receipt, (7) Limited IB services, (8) Lack of bank staff presence, (9) Previous unsuccessful experience, and (10) Not being widely used. Those attribute lead to 5 personal values (V): (1) Convenience, (2) Security, (3) Economy, (4) Compatibility, and (5) Resistance to Change.

Hongxia, Xianhao, and Weidan (2011) conducted a study in China to investigate both drivers and barriers of mobile payment acceptance. The research findings revealed two keys barriers namely the perceived risks and the costs. The perceived risk means the security concern due to the infancy of the market and uncertainty of the mobile payment environment and the costs involve direct transaction fees, access cost and new mobile phone cost.

Issahaku (2012) found 4 main groups of challenges for implementation of electronic payment in Ghana, including Security with PIN for debit cards authentication, Infrastructure in term of connectivity and cost, Legal, regulatory and Socio-cultural issues with a high illiteracy rate and highly unbanked population which requires more training for customers to understand and adopt e-payment.

From the research findings of Okifo and Igbunu (2015), customer resistances to adopt the electronic payment system in Nigeria are due to: (1) lack of awareness of and information about the benefits of e-payment system, (2) fear of risk, (3) unwell trained personnel in the key 
merchants \& organizations, (4) cash habit, (5) people resistance to new payment mechanisms, (6) security (disclosure of private information, counterfeiting and illegal alteration of payment data), (7) low literacy rate, (8) high internet cost, and (9) unreliable power supply. In addition, the e-payment systems are also seen as an imposition, such as lack of uniform payment platforms, lack of adequate infrastructure, platform security and lack of seriousness by banks.

Arango-Arango and Suarez-Ariza (2017) conducted a study in five main Colombian cities: Barranquilla, Bogota, Bucaramanga, Cali, and Medellin with 2 surveys on consumers and merchants to understand reasons for low electronic payments usage. The study found that factors impeding the growth of electronic payments come from both consumers and merchants. For the consumer side, there are 2 key areas: access to transactional services and the use of electronic payment instruments. For accessibility, the main reasons are low levels of income, wealth and education, privacy and inadequate product design and high costs against operation cash. The instruments are impacted by a high preference for cash: speed, price discounts, and budgetary control and low acceptance by merchants (only 13\% chance of electronic payment being accepted by merchants). For merchants, the reasons include high costs and low perceived gains relative to cash payment, unbanked population and worry about informality status and low perceived demand of e-payments by clients.

Sivathanu (2018) uses the IR Theory to explain why customers are reluctant to use epayment in India. The study found five key barriers that should be broken down to make epayment systems more applicable and user-friendly to customers. They are usage barriers, value barriers, risk barriers, traditional barriers, and image barriers.

Dinh, Nguyen, and Nguyen (2018) provide insights into motivations and barriers affecting consumer behaviors toward mobile payments in Vietnam. The study highlights the main barriers that still inhibits mobile payment usage in Vietnam. Generally, Vietnamese consumers show a lack of trust in mobile payment technology and service providers. In particular, they concerned much about privacy, security, fraud of bank accounts and card numbers, and payment transaction errors from the e-payment system. Another inhibitor is low availability with limited opportunities to use mobile payment services. The perceived complexity due to users' lack of knowledge and unclear instructions are other barriers. The last inhibitor is the cash habit of Vietnamese people.

All barriers from the above studies are inherited for this research and are used as the foundation for the initial study. However, they are classified into the Attribute/ Consequence/ Value levels to enable laddering interviews in a qualitative study. In total, there are 14 attributes of e-payment, 10 of consequences, and 6 of personal values.

\section{Methodology}

\section{Method}

The main purpose of this study is to investigate reasons preventing customers from accepting and using electronic payment by employing MEC theory with hard-laddering interviews to collect data. There are 2 stages in the study. In the first stage, based on attributes (A), consequences (C), and values (V) from previous studies, soft-laddering interviews were 
conducted with 02 specialists in electronic payment (01 is Customer Center Director in one commercial bank and the other is Head of Product Development Division in another commercial bank) and 03 customers to modify the A-C-V list that matches with the context of Ho Chi Minh City. After 05 soft-laddering interviews, 15 attributes (A) of e-payment (01 new A added), 12 Consequences (C) (02 new Cs added) and 6 Values (V) are used for the hard-laddering interview, totally. The finalized list of A-C-V is presented in Table 1.

\section{Table 1}

Finalized A-C-V

\begin{tabular}{|c|c|c|c|c|}
\hline \multirow{2}{*}{ No } & \multirow{2}{*}{ Stakeholders } & From previous studies & Finalized after interviews & Code \\
\hline & & \multicolumn{3}{|c|}{ ATTRIBUTES } \\
\hline 1 & \multirow{7}{*}{$\begin{array}{l}\text { Internal } \\
\text { factors: } \\
\text { Users }\end{array}$} & Cash habit & Cash habit & A1 \\
\hline 2 & & $\begin{array}{l}\text { Lack of information about } \\
\text { electronic payment and its } \\
\text { benefits }\end{array}$ & $\begin{array}{l}\text { Lack of information about electronic } \\
\text { payment and its benefits }\end{array}$ & A2 \\
\hline 3 & & Need to have a bank card & Need to have a bank card & A3 \\
\hline 4 & & $\begin{array}{l}\text { No computer / no } \\
\text { smartphone/ no Internet } \\
\text { connection }\end{array}$ & $\begin{array}{l}\text { Need to have connected } \\
\text { laptop/smartphone }\end{array}$ & A4 \\
\hline 5 & & $\begin{array}{l}\text { Enter billing and } \\
\text { card information }\end{array}$ & $\begin{array}{l}\text { Need to enter billing and card } \\
\text { information }\end{array}$ & A5 \\
\hline 6 & & Lack of a receipt & Lack of a sealed receipt & A6 \\
\hline 7 & & $\begin{array}{l}\text { Electronic money is not } \\
\text { real }\end{array}$ & Electronic money is not real & A7 \\
\hline 8 & \multirow{2}{*}{$\begin{array}{l}\text { External } \\
\text { factors: }\end{array}$} & $\begin{array}{l}\text { Previous unsuccessful } \\
\text { experience }\end{array}$ & Previous unsuccessful experience & A8 \\
\hline 9 & & Not being widely used & Not being widely used & A9 \\
\hline 10 & \multirow{3}{*}{\begin{tabular}{|l} 
1. Banks or \\
Financial \\
institutions \\
2.Services \\
providers \\
3. Merchants \\
4. \\
Policymakers
\end{tabular}} & $\begin{array}{l}\text { E-payment market is } \\
\text { immature (lack of adequate } \\
\text { infrastructure and uniform } \\
\text { payment platforms) }\end{array}$ & $\begin{array}{l}\text { E-payment market is immature (lack } \\
\text { of adequate infrastructure and } \\
\text { uniform payment platforms) }\end{array}$ & A10 \\
\hline 11 & & & $\begin{array}{l}\text { Transaction fee/No special } \\
\text { discount for E-payment }\end{array}$ & A11 \\
\hline 12 & & $\begin{array}{l}\text { Complicated payment } \\
\text { procedure }\end{array}$ & Complicated payment procedure & A12 \\
\hline \multirow[t]{2}{*}{13} & & Internet Environment & $\begin{array}{l}\text { Information security system is not } \\
\text { good }\end{array}$ & A13 \\
\hline & & $\begin{array}{l}\text { Not timely support } \\
\text { services, including }\end{array}$ & $\begin{array}{l}\text { Not timely support services, } \\
\text { including unwell trained staff }\end{array}$ & A14 \\
\hline
\end{tabular}




\begin{tabular}{|c|c|c|c|c|}
\hline \multirow{2}{*}{ No } & \multirow{4}{*}{ Stakeholders } & From previous studies & Finalized after interviews & Code \\
\hline & & \multicolumn{3}{|c|}{$\begin{array}{l}\text { ATTRIBUTES } \\
\end{array}$} \\
\hline & & \multicolumn{3}{|l|}{ unwell trained staff } \\
\hline 15 & & $\begin{array}{l}\text { Unavailable } \\
\text { regulators to protect } \\
\text { users }\end{array}$ & No legal to protect users & A15 \\
\hline \multicolumn{5}{|c|}{ CONSEQUENCES } \\
\hline 1 & \multicolumn{2}{|c|}{ Do not want to know/learn about EPS } & No need to learn about e- payment & C1 \\
\hline 2 & \multicolumn{2}{|c|}{$\begin{array}{l}\text { Feel uncomfortable, unclear when } \\
\text { using e- payment }\end{array}$} & Not clearly understand & $\mathbf{C 2}$ \\
\hline 3 & \multicolumn{2}{|c|}{ Time-consuming } & Time-consuming & $\mathbf{C 3}$ \\
\hline 4 & \multicolumn{2}{|c|}{ Purchase computer/phone } & Costly/ no discount & $\mathbf{C 4}$ \\
\hline 5 & \multicolumn{2}{|c|}{ Make mistakes by users } & $\begin{array}{l}\text { Possibility of making mistakes by } \\
\text { users }\end{array}$ & C5 \\
\hline 6 & \multicolumn{2}{|c|}{ No transaction evidence } & No transaction evidence & C6 \\
\hline 7 & \multicolumn{2}{|l|}{ Feel insecure } & No trust & $\mathbf{C 7}$ \\
\hline 8 & \multicolumn{2}{|c|}{$\begin{array}{l}\text { Usage difficulty, including password } \\
\text { required for the transaction }\end{array}$} & Usage difficulty & C8 \\
\hline 9 & \multicolumn{2}{|c|}{ 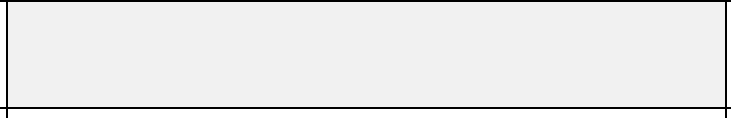 } & $\begin{array}{l}\text { Not all merchants accept E- } \\
\text { payments }\end{array}$ & C9 \\
\hline 10 & \multicolumn{2}{|c|}{ Payment transaction errors } & Payment system errors & C10 \\
\hline 11 & \multicolumn{2}{|c|}{$\begin{array}{l}\text { Possible internet threats: Fraud of bank } \\
\text { accounts and card number }\end{array}$} & $\begin{array}{l}\text { Risk of disclosing personal } \\
\text { information, card and account }\end{array}$ & C11 \\
\hline 12 & & & Risk of losing money & C12 \\
\hline \multicolumn{4}{|c|}{ VALUES } & \\
\hline 1 & \multicolumn{2}{|l|}{ Economy } & $\begin{array}{l}\text { Using E-payment is not } \\
\text { economical }\end{array}$ & V1 \\
\hline 2 & \multicolumn{2}{|l|}{ Security } & Using E-payment is not safe & $\mathbf{V} 2$ \\
\hline 3 & \multicolumn{2}{|l|}{ Convenience } & $\begin{array}{l}\text { Using E-payment is not } \\
\text { convenient }\end{array}$ & V3 \\
\hline 4 & \multicolumn{2}{|l|}{ Control } & $\begin{array}{l}\text { Using E-payment doesn't bring } \\
\text { financial control }\end{array}$ & V4 \\
\hline 5 & \multicolumn{2}{|l|}{ Efficiency } & Using E-Payment is not efficient & V5 \\
\hline 6 & \multicolumn{2}{|c|}{ Change resistance } & I'm not willing to use E-payment & v6 \\
\hline
\end{tabular}

Source: The researcher's data analysis 
Then, in the second stage, Association Pattern Technique (APT) is followed to build the questionnaire for hard-laddering interview including two matrices (A-C and C-V) of internal factors so that respondents will select the attributes, associated consequences, and values that make them reluctant to e-payment (See Table $2 \& 3$ ). Similarly, external factors will be explored in the last two questions.

\section{Table 2}

Matrix of attributes (A) and consequences (C)

\begin{tabular}{|c|c|c|c|c|c|c|c|c|c|c|c|c|}
\hline & $\mathrm{C} 1$ & $\mathrm{C} 2$ & $\mathrm{C} 3$ & $\mathrm{C} 4$ & $\mathrm{C} 5$ & $\mathrm{C} 6$ & $\mathrm{C} 7$ & $\mathrm{C} 8$ & $\mathrm{C} 9$ & $\mathrm{C} 10$ & $\mathrm{C} 11$ & $\mathrm{C} 12$ \\
\hline A1 & & & & & & & & & & & & \\
\hline A2 & & & & & & & & & & & & \\
\hline A3 & & & & & & & & & & & & \\
\hline A4 & & & & & & & & & & & \\
\hline A5 & & & & & & & & & & & & \\
\hline A6 & & & & & & & & & & & & \\
\hline A7 & & & & & & & & & & & \\
\hline A8 & & & & & & & & & & & & \\
\hline A9 & & & & & & & & & & & & \\
\hline A10 & & & & & & & & & & & \\
\hline A11 & & & & & & & & & & & & \\
\hline A12 & & & & & & & & & & & & \\
\hline A13 & & & & & & & & & & & & \\
\hline A14 & & & & & & & & & & & \\
\hline A15 & & & & & & & & & & & \\
\hline
\end{tabular}

Source: The researcher's data analysis

Table 3

Matrix of consequences (C) and values (V)

\begin{tabular}{|l|l|l|l|l|l|l|}
\hline & V1 & V2 & V3 & V4 & V5 & V6 \\
\hline C1 & & & & & & \\
\hline $\mathrm{C} 2$ & & & & & & \\
\hline C3 & & & & & & \\
\hline C4 & & & & & & \\
\hline C5 & & & & & & \\
\hline C6 & & & & & & \\
\hline C7 & & & & & & \\
\hline
\end{tabular}




\begin{tabular}{|l|l|l|l|l|l|l|}
\hline $\mathrm{C} 8$ & & & & & & \\
\hline $\mathrm{C} 9$ & & & & & & \\
\hline $\mathrm{C} 10$ & & & & & & \\
\hline $\mathrm{C} 11$ & & & & & & \\
\hline $\mathrm{C} 12$ & & & & & & \\
\hline
\end{tabular}

Source: The researcher's data analysis

\section{Sampling}

Because of the unpopularity of hard- laddering survey, respondents easily get confused when answering the questionnaire. Therefore, each respondent was approached individually in person and asked appropriate questions to target the right person for the survey. The requirement to be a surveyor is that (1) Customers know about electronic payment but do not use and they conduct most of their transactions by cash, or (2) Customers who had used electronic payment before but no longer use it, or (3) Customers limit the use of e-payment in their transactions. Then, each respondent needs from 15 to 20 minutes to complete the questionnaire.

Costa, Dekker, and Jongen (2004) proposed a sample size of $\geq 50$ for a study using a hard laddering interview technique. Therefore, the minimum sample size of this study should be $\geq 50$. After the data collection, there were 203 qualified questionnaires used for analysis.

\section{Data analysis}

In order to analyze the means-end data from laddering interviews, Hofstede et al. (1998) proposed and validated a survey-based study named Association Pattern Technique. There are three steps in the APT (Reynolds \& Gutman, 1988): (1) Finalize the list of three groups of attributes (A), consequences (C) and values (V); (2) Create the association pattern matrices from the first results where respondents are supposed to mark in a cell and a linkage is perceived; and (3) Construct the Hierarchical Value Map (HVM) by analyzing the links between elements from the two A-C and C-V matrices.

In order to construct the HVM, the first step is to quantify the A-C and C-V matrices according to the APT model. The responses for the 2 above matrices are "Yes" or "No". If the answer is "Yes", there will be a linkage for A-C or C-V and 1 point will be given. On the contrary, if the choice is "No", there is no linkage between them and a score of 0 will be given. Summarizing all points of each cell will show how many times the linkage is mentioned. The quantitative results of two relational matrices are used to construct the HVM. A HVM is a map in which all linkages among Attributes, Consequences, and Values (A-C-V) are expressed in the form of a chart to provide a visual look at the results of this study and to help them focus on the issues that need to be addressed.

The next step is to balance the amount of information from the two relational matrices and retain $\mathrm{A} / \mathrm{C} / \mathrm{V}$ elements and their linkages to create a final, clear and simple map with sufficient information for an explanation. This balance depends on the quantity of sample size 
and the uniformity of information from respondents. It is often expressed by the cut- off point which indicates the minimum number that a link must have to appear in the hierarchical value map. For example, if the cut-off point is 4, those linkages that appear smaller than 4 will not be retained in the HVM. The purpose of the cut-off is to distinguish the important linkages and omit the rest in order to achieve useful and interpretable HVMs. Kang, Kang, Yoon, and Kim (2014) suggested a cut-off point of 5\% of the total cell number of the A-C matrix and the cutoff point for the C-V matrix is suggested to be 3 to 5 linkages. The HVM covers 3 levels of abstraction. The Attribute (A) is the lowest level of abstraction and located at the bottom, the value $(\mathrm{V})$ is the highest level and at the top of the map. A possible HVM for the study of barriers to e-payment adoption is illustrated in Figure 1.

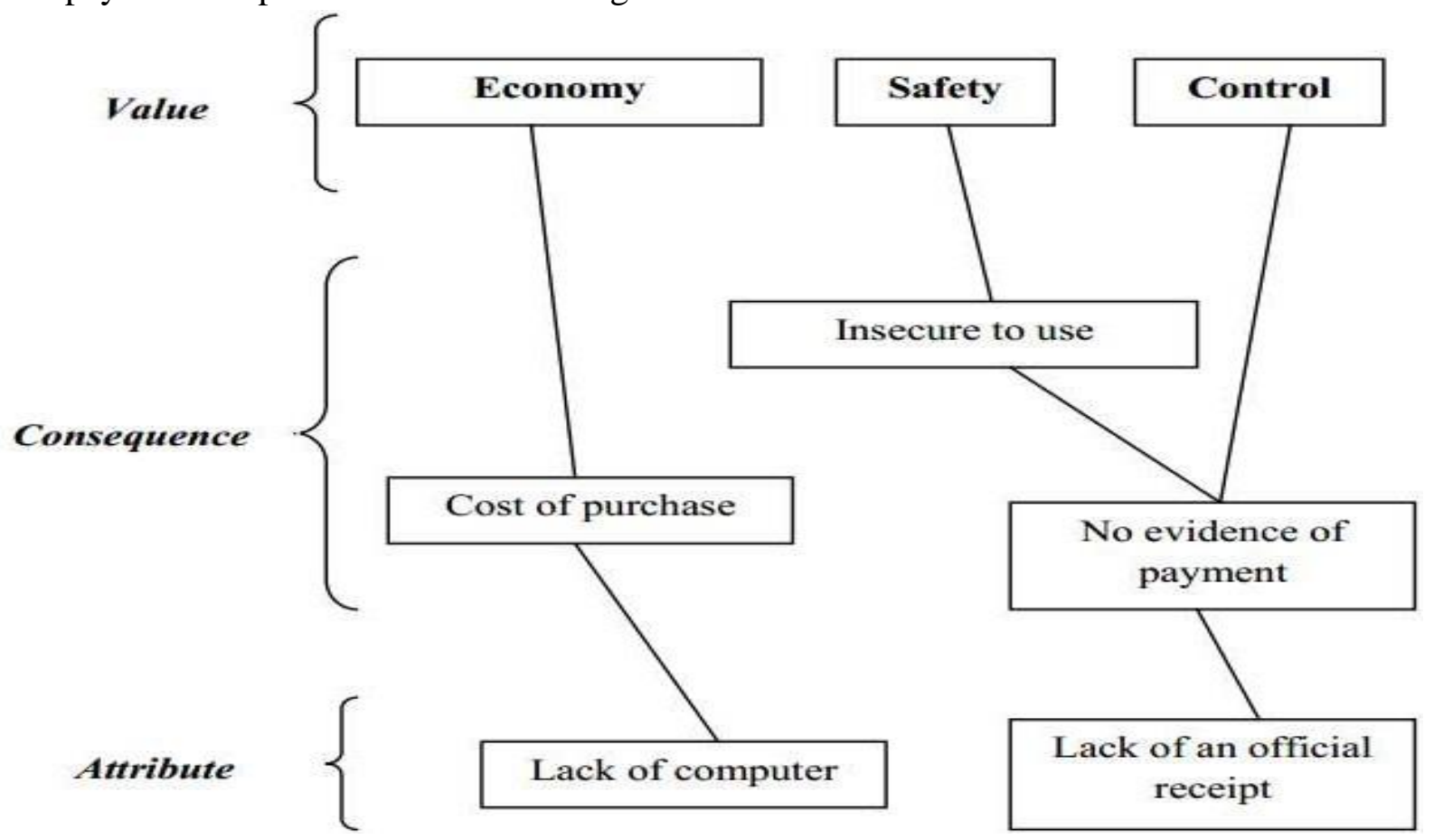

Figure 1. An example HVM for the study of barriers to e-payment adoption

\section{Research findings}

Data description

Table 4 summarises characteristics of the sample, including: age, gender, and payment methods. Based on the qualifiedquestionnaires, 55\% of the respondents are under 35 and this echoes the information in the article of Loi (2017) mentioned in the Introduction. A majority of the population is under 45 (171 out of 203 respondents) and around $80 \%$ of them mostly or totally use cash in daily transactions. Therefore, the sample meets the requirements of the proposed target population. 
Table 4

Sample' description

\begin{tabular}{|l|c|c|c|c|c|c|}
\hline \multicolumn{5}{|c|}{ Description } & Total \\
\hline Age & $18-25$ & $26-35$ & $36-45$ & $46-55$ & $>55$ & \\
\hline No. & 51 & 61 & 59 & 23 & 9 & 203 \\
\hline Gender & Male & Female & 105 & \\
\hline No. & \multicolumn{2}{|c|}{98} & Same ratio & \\
\hline $\begin{array}{l}\text { Payment } \\
\text { methods }\end{array}$ & $\begin{array}{l}100 \% \text { by cash } \\
\text { No. }\end{array}$ & Mostly by cash & & 42 & 203 \\
\hline
\end{tabular}

Source: Data analysis result of the research

\section{Implication matrices}

The matrix in Table 5 illustrates the attributes that make consumers not willing to use Epayment and the consequences of those attributes. Each cell in the matrix represents a link. There are 126 and 54 links, which are mentioned and not mentioned, respectively. The mostly-mentioned links are $(\mathrm{A} 1, \mathrm{C} 1)$ at $86,(\mathrm{~A} 11, \mathrm{C} 4)$ at 85 or $(\mathrm{A} 13, \mathrm{C} 11)$ at 81 . On the other hand, there are also links with a minimum occurrence at 1 , such as (A3, C5), (A5, C1) or (A7, C4). The attributes A9 and A10 have linkages to most of the consequences while A11 is only linked to a few consequences. All attributes are associated with the consequence of C9, whereas C6 and C11 are less linked to attributes.

Table 5

A-C matrix about reasons why customers are unwilling to use E-payment

\begin{tabular}{|c|c|c|c|c|c|c|c|c|c|c|c|c|}
\hline & $\mathbf{C 1}$ & $\mathbf{C 2}$ & $\mathbf{C 3}$ & $\mathbf{C 4}$ & $\mathbf{C 5}$ & $\mathbf{C 6}$ & $\mathbf{C 7}$ & $\mathbf{C 8}$ & $\mathbf{C 9}$ & $\mathbf{C 1 0}$ & $\mathbf{C 1 1}$ & $\mathbf{C 1 2}$ \\
\hline $\mathbf{A 1}$ & $\mathbf{8 6}$ & 42 & 20 & 12 & 22 & 11 & 26 & 15 & 28 & 0 & 0 & $\mathbf{0}$ \\
\hline $\mathbf{A 2}$ & 17 & $\underline{\mathbf{7 0}}$ & 11 & 4 & 8 & 2 & 16 & 11 & 16 & 0 & 0 & $\mathbf{0}$ \\
\hline $\mathbf{A 3}$ & 2 & 6 & $\underline{\mathbf{7 6}}$ & 19 & 1 & 2 & 6 & 7 & 8 & 0 & 0 & $\mathbf{0}$ \\
\hline $\mathbf{A 4}$ & 4 & 3 & 13 & 33 & 8 & 0 & 4 & 16 & 43 & 0 & 0 & $\mathbf{0}$ \\
\hline $\mathbf{A 5}$ & 1 & 3 & 20 & 0 & 47 & 0 & 2 & 8 & 17 & 0 & 0 & $\mathbf{0}$ \\
\hline $\mathbf{A 6}$ & 0 & 0 & 0 & 0 & 3 & $\underline{\mathbf{5 0}}$ & 8 & 2 & 1 & 0 & 0 & $\mathbf{0}$ \\
\hline $\mathbf{A 7}$ & 4 & 4 & 1 & 1 & 0 & 3 & 20 & 3 & 2 & 0 & 0 & $\mathbf{0}$ \\
\hline $\mathbf{A 8}$ & 0 & 4 & 15 & 2 & 15 & 1 & 17 & 8 & 13 & 0 & 0 & $\mathbf{0}$ \\
\hline $\mathbf{A 9}$ & 48 & 35 & 6 & 5 & 0 & 0 & 20 & 23 & $\underline{\mathbf{5 5}}$ & 10 & 16 & $\mathbf{1 0}$ \\
\hline $\mathbf{A 1 0}$ & 13 & 24 & 18 & 1 & 0 & 0 & 36 & 21 & 41 & 41 & 31 & $\mathbf{3 3}$ \\
\hline $\mathbf{A 1 1}$ & 0 & 8 & 2 & $\underline{\mathbf{8 5}}$ & 0 & 0 & 0 & 0 & 5 & 1 & 0 & $\mathbf{3}$ \\
\hline
\end{tabular}




\begin{tabular}{|c|c|c|c|c|c|c|c|c|c|c|c|c|}
\hline & C1 & C2 & C3 & C4 & C5 & C6 & C7 & C8 & C9 & C10 & C11 & C12 \\
\hline $\mathbf{A 1 2}$ & 3 & 6 & 39 & 2 & 0 & 0 & 10 & 35 & 23 & 17 & 6 & $\mathbf{1 2}$ \\
\hline $\mathbf{A 1 3}$ & 2 & 3 & 0 & 0 & 0 & 0 & 41 & 1 & 5 & 44 & $\underline{\mathbf{8 1}}$ & $\mathbf{7 0}$ \\
\hline $\mathbf{A 1 4}$ & 2 & 8 & 24 & 2 & 0 & 0 & 21 & 7 & 30 & 9 & 4 & $\mathbf{1 7}$ \\
\hline $\mathbf{A 1 5}$ & 4 & 7 & 1 & 0 & 0 & 0 & 21 & 1 & 9 & 17 & 35 & $\mathbf{5 8}$ \\
\hline
\end{tabular}

Source: Data analysis result of the research

The matrix in Table 6 demonstrates the relationship between consequences (which are from the main reasons making consumers not willing to use E-payment) and underlying values affected by those consequences. Similar to the above analysis, the number of occurrences of a link between consequence $(\mathrm{C})$ and value $(\mathrm{V})$ is also represented by numbers in the matrix. There are 3 pairs $(\mathrm{C}, \mathrm{V})$ not forming the relationship since the number of cells in the matrix is zero $(0)$. The number in the cell $(\mathrm{C} 9, \mathrm{~V} 3)$ is 118 and this is the largest number of occurrences in this matrix. Most of the consequences are associated with 6 values except C6 and C11, in which C6 only links to 4 values. Columns V2, V3, and V4 do not contain zero (0) meaning that all 12 consequences affect these three values of the respondents.

Table 6

$\mathrm{C}-\mathrm{V}$ matrix about reasons why customers are unwilling to use E-payment

\begin{tabular}{|l|c|c|c|c|c|c|}
\hline & $\mathbf{V 1}$ & $\mathbf{V 2}$ & $\mathbf{V 3}$ & $\mathbf{V 4}$ & $\mathbf{V 5}$ & V6 \\
\hline $\mathbf{C 1}$ & 23 & 49 & 33 & 21 & 10 & 51 \\
\hline $\mathbf{C 2}$ & 17 & $\underline{\mathbf{7 7}}$ & 43 & 24 & 25 & 14 \\
\hline $\mathbf{C 3}$ & 25 & 14 & 76 & 5 & 69 & 12 \\
\hline $\mathbf{C 5}$ & $\underline{\mathbf{1 1 5}}$ & 16 & 16 & 30 & 21 & 4 \\
\hline $\mathbf{C 6}$ & 4 & 64 & 17 & 18 & 10 & 8 \\
\hline $\mathbf{C 7}$ & 1 & 47 & 4 & 16 & 0 & 0 \\
\hline $\mathbf{C 8}$ & 4 & 32 & 72 & 12 & 23 & 17 \\
\hline $\mathbf{C 9}$ & 4 & 36 & $\underline{\mathbf{1 1 8}}$ & 17 & 32 & 14 \\
\hline $\mathbf{C 1 0}$ & 5 & $\mathbf{7 1}$ & 20 & 13 & 21 & 7 \\
\hline $\mathbf{C 1 1}$ & 0 & $\underline{\mathbf{1 0 2}}$ & 11 & 20 & 13 & 11 \\
\hline $\mathbf{C 1 2}$ & 11 & $\underline{\mathbf{9 5}}$ & 7 & 41 & 15 & 10 \\
\hline
\end{tabular}

Source: Data analysis result of the research

\section{Hierarchical Value Map}

The HVM is created by constructing the link among attributes, consequences, and values or $\mathrm{A}-\mathrm{C}-\mathrm{V}$ links from the results of two relational matrices. As mentioned in 
Methodology, this paper uses the method suggested by Kang et al. (2014). The selected cut-off value is $5 \%$ of the total cell number in the A-C matrix. The matrix in Table 5 has a total of 180 cells $\left(15 \mathrm{~A}^{*} 12 \mathrm{C}\right)$; therefore, 9 cells $(5 \% * 180)$ with the highest number of occurrences are selected. Those cells in bold and underlined are retained in Table 5. From that, 50 is the cut-off value for A-C matrix. Table 7 below shows in detail 9 important links retained.

\section{Table 7}

Retained A-C links with the cut-off value at 5\%

\begin{tabular}{|c|c|c|c|}
\hline No & $\begin{array}{l}\text { Number of } \\
\text { occurrences }\end{array}$ & Coded link & Detailed Linkage \\
\hline 1 & 86 & A1-C1 & $\begin{array}{l}\text { Cash habit make customers unwilling to use e-payment } \\
\text { because e-payment is more time consuming than cash }\end{array}$ \\
\hline 2 & 85 & A11-C4 & $\begin{array}{l}\text { Need to pay a transaction fee or no discount for E- } \\
\text { payment --> Costly for using E-payment }\end{array}$ \\
\hline 3 & 81 & A13-C11 & $\begin{array}{l}\text { The information security system of E-payment is not } \\
\text { good --> Risk of disclosing personal information, card } \\
\text { and account }\end{array}$ \\
\hline 4 & 76 & A3-C3 & $\begin{array}{l}\text { Need to have a bank card for E-payment transaction --> } \\
\text { time consuming to create a bank card }\end{array}$ \\
\hline 5 & 70 & $\mathrm{~A} 2-\mathrm{C} 2$ & $\begin{array}{l}\text { Lack of information on E-payment and its benefits --> } \\
\text { Not clearly understand about E-payment }\end{array}$ \\
\hline 6 & 70 & A13-C12 & $\begin{array}{l}\text { The information security system of E-payment is not } \\
\text { good --> Risk of losing money }\end{array}$ \\
\hline 7 & 58 & A15-C12 & $\begin{array}{l}\text { No available legal to protect E-payment users --> Risk } \\
\text { of losing money }\end{array}$ \\
\hline 8 & 55 & A9-C9 & $\begin{array}{l}\text { E-payment is not being widely used --> Not always } \\
\text { accepted by merchants }\end{array}$ \\
\hline 9 & 50 & A6-C6 & $\begin{array}{l}\text { Lack of a sealed receipted for E-payment --> No } \\
\text { transaction evidence }\end{array}$ \\
\hline
\end{tabular}

Source: Data analysis result of the research

From the 9 A-C links retained above, there are 8 consequences of those links which are further considered, C1, C2, C3, C4, C6, C9, C11, and C12. According to Kang et al. (2014), the cut point of the $\mathrm{C}-\mathrm{V}$ matrix is defined so that the common consequence elements of these two matrices are from 3 to 5. Therefore, the cut-off value for $\mathrm{C}-\mathrm{V}$ matrix is 77 . Numbers in bold and underlined in Table 6 represent the number greater than or equal to the cut-off value. With the cut-point of 77, there are 5 consequences: C2, C4, C9, C11, C12 and 5 corresponding $\mathrm{C}-\mathrm{V}$ 
links: C2-V2, C4-V1, C9-V3, C11-V2, and C12-V2 are retained. From these 5 consequences, it is possible to identify $6 \mathrm{~A}-\mathrm{C}$ links containing these 5 consequence elements in the $9 \mathrm{~A}-\mathrm{C}$ links above. 6 A-C links along with $5 \mathrm{C}-\mathrm{V}$ links create 6 linkages A-C-V as presented in Table 8.

\section{Table 8}

Retained A-C-V linkages after defining cut-off values for A-C and C-V matrices

\begin{tabular}{|c|c|c|l|c|c|}
\hline No & $\begin{array}{c}\text { Number of } \\
\text { occurrences }\end{array}$ & $\begin{array}{c}\text { Coded } \\
\text { C-V link }\end{array}$ & \multicolumn{1}{|c|}{ Detailed Link } & $\begin{array}{c}\text { Coded } \\
\text { A-C link }\end{array}$ & $\begin{array}{c}\text { Coded A-C- } \\
\text { V linkage }\end{array}$ \\
\hline 1 & 118 & C9-V3 & $\begin{array}{l}\text { Not always accepted by merchants --> } \\
\text { using E-payment is not convenient }\end{array}$ & A9-C9 & A9-C9-V3 \\
\hline 2 & 115 & C4-V1 & $\begin{array}{l}\text { Using E-payment is costly --> using E- } \\
\text { payment is not economical }\end{array}$ & A11-C4 & A11-C4-V1 \\
\hline 3 & 102 & C11-V2 & $\begin{array}{l}\text { Risk of disclosing personal information, } \\
\text { card and account --> Using E-payment is } \\
\text { not safe }\end{array}$ & A13-C11 & A13-C11-V2 \\
\hline 4 & 95 & C12-V2 & $\begin{array}{l}\text { Risk of losing money --> using E- } \\
\text { payment is not safe }\end{array}$ & A13-C12 & A13-C12-V2 \\
\cline { 4 - 7 } & 77 & C2-V2 & $\begin{array}{l}\text { Not clearly understand about E-payment } \\
-->\text { Using E-payment is not safe }\end{array}$ & A2-C2 & A2-C2-V2 \\
\hline 5 & \multirow{2}{*}{5} & & A15-C12-V2 \\
\hline
\end{tabular}

Source: Data analysis result of the research

The six A-C-V linkages are used to construct the HVM, of which there are 3 levels from the lowest abstraction level to the highest abstraction level A-C-V. The linkages between these elements are represented by arrow-lines with the associated number of occurrences. Among 6 A-C-V linkages, there are only 2 links that started with the same A13: A13-C11-V2 and A13C12-V2. Attribute A13 has been associated with both $\mathrm{C} 11$ and $\mathrm{C} 12$. Therefore from A13, there are two arrow directions to $\mathrm{C} 11$ and $\mathrm{C} 12$. Both Cs connect with $\mathrm{V} 2$, there should be two arrows coming from $\mathrm{C} 11$ \& $\mathrm{C} 12$ to $\mathrm{V} 2$. All numbers of occurrences will be attached to the corresponding arrow lines. In that way, the linkages A13-C11-V2 and A13-C12-V2 are represented in the Value map as below: 

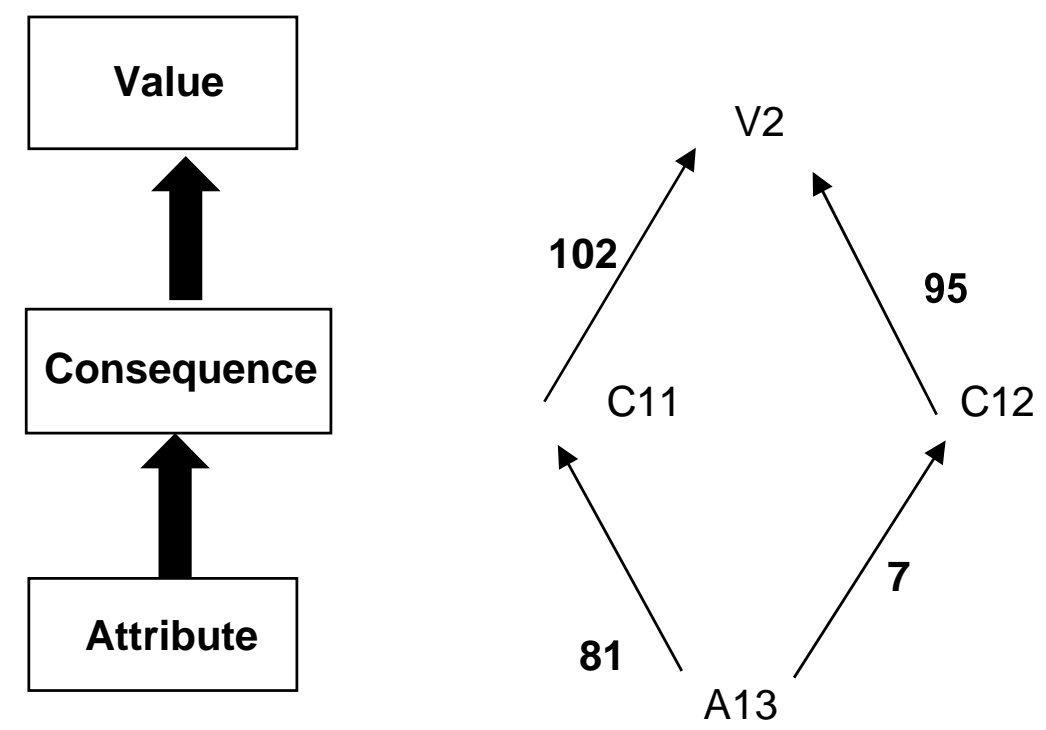

Figure 2. The linkages A13-C11-V2 and A13-C12-V2 in HVM

Similarly, all A-C-V linkages are established by the same say to have the HVM as presented in Figure 3 below. In order to read the HVM, we should start from a specific attribute (A) and follows the arrow direction to the consequence $(\mathrm{C})$ and then to the value (V). For example, the linkage A11-C4-V1 in the Value Map shown in Figure 3 can be read like this: Because "customers need to pay transaction fee or no discount for e-payment", customers feel it is costly to use e-payment method. "Being costly" makes them feel that using e-payment is not economical.
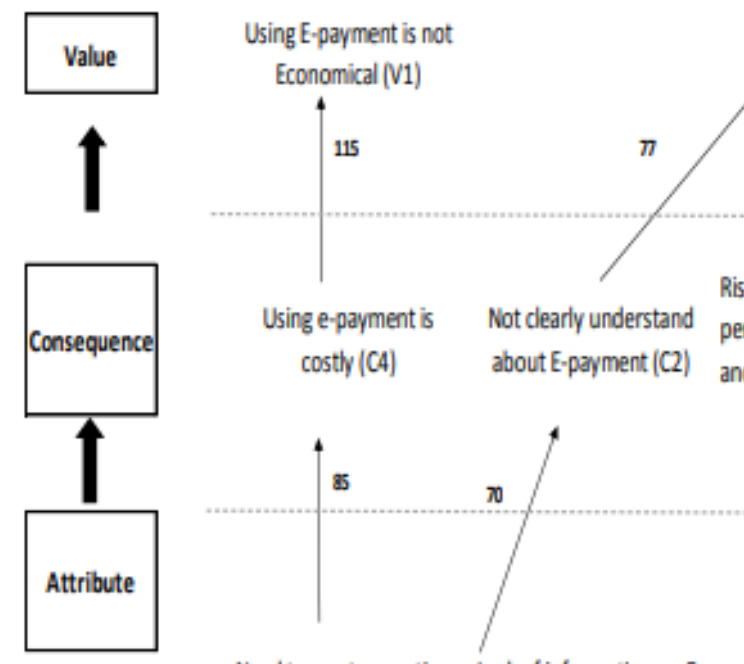

Using E-payment is not Safe(V2)

Using E-payment is
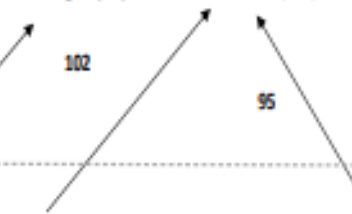

not conyenient (V3)

Using e-payment is Not clearly understand costly (C4) about E-payment (C2)

Risk of disclosing

Risk of losing maney ( $\mathrm{C} 12$ )

personal infor., card
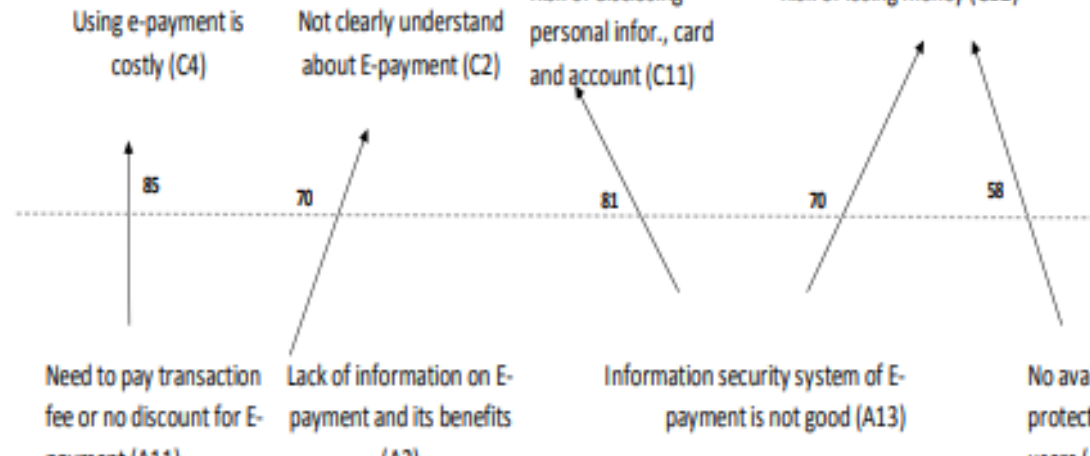

and account (C11)

(A2)

$$
\begin{aligned}
& \begin{array}{l}
\text { No available legal to E-payment is not } \\
\text { protect E-payment }
\end{array} \\
& \text { wisers (A15) }
\end{aligned}
$$

Not always accepted by merchants (C9)

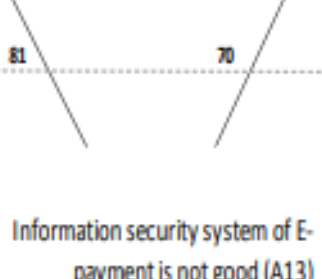

payment is not good (A13)

Figure 3. HVM about reasons why customers are unwilling to use E -payment

There are two important issues when reading an HVM: the inter-link between elements and the core elements of which there are many links leading to in the HVM. The numbers attached to the link are the numbers of occurrences of linkages or the strong level of the links. Based on Figure 3, the linkage between A11 and C4 is the strongest link with the highest 
number of occurrences (85) among A-C links. The link between C9 and V3 is repeated 118 times representing the strongest $\mathrm{C}-\mathrm{V}$ linkage.

In terms of Value element, V2 is obviously the only Value with 3 Consequences linked to while the other two Values only have 1 link with the Consequence. Therefore, "Safety" is the core value when considering A-C-V linkage explaining why consumers reluctant to use Epayment.

\section{Discussion}

The HVM shows 5 main attributes of E-payment making customers unwilling to use Epayment: (1) A2 - "Lack of information on E-payment and its benefits"; (2) A13 - "Information security system of E-payment is not good"; (3) A15 - "No available laws to protect E-payment users"; (4) A9 - "E-payment is not being widely used"; (5) A11- "Need to pay a transaction fee or no discount for E-payment". There are some points that can be easily recognized from the HVM.

Firstly, A11 is the attribute selected by most of the customers. Secondly, these five attributes make customers feel that E-payment does not bring them any economic benefits (V1), safety (V2) and convenience (V3). Thirdly, it is obvious that most of the respondents are interested in V2 and there are 3 per 5 linkages leading to this value. Lastly, $03 \mathrm{~A}-\mathrm{C}-\mathrm{V}$ linkages, A11-C4-V1 (Need to pay transaction fee or no discount for E-payment $\rightarrow$ Using E-payment is costly $\rightarrow$ Using E-payment is not Economical); A13-C11-V2 (Information security system of E-payment is not good $\rightarrow$ Risk of disclosing information, card and account $\rightarrow$ Using E-payment is not Safe); and A9-C9-V3 (E-payment is not being widely used $\rightarrow$ Not always accepted by merchants $\rightarrow$ Using E-payment is not convenient) are the most-noticed linkages with high number of occurrences by respondents.

Focusing on the consequence level, C12 (Risk of losing money) is the most significant element with 128 occurrences. This consequence is related to the "Information security system of E-payment is not good" (A13), and "No available laws to protect E-payment users" (A15) at 70 and 58 occurrences, respectively. In recent years, there were many cases of losing money in the banking sector (in Vietcombank, Dong A Bank, Agribank, etc.) associated with the banking security system including threats of viruses spread, a leak of information about account and card numbers as well as the attack of hackers. Those cases show the weakness in the existing security system which makes users feel unsafe and unwilling to use electronic payments. However, up to date, there has not been a completed legal document regulating the process of providing epayment or e-banking services to create a coherent legal framework for the application of technology. The cases also show that current legal laws are insufficient, out of date and unadapted to the change of technology and the complexity of hackers. This unsafe feeling makes clients reluctant to change from Cash payment to electronic payments.

The second significant consequence is C4 (Using E-payment is costly) with 85 occurrences from A11 (Need to pay transaction fee or No discount for E-payment). Most banks in Vietnam today require bank fees for any online transactions but charge no additional fee for cash transactions. The higher the amount of transaction, the higher the cost is applied for users. Therefore, to motivate customers to switch from using traditional payment (cash) to e-payment, 
a bonus or discount for e-payment transactions should be applied. In developed countries, retailers pay a commission of 2 to $3 \%$ for electronic payments. This is really a good incentive for users of electronic payments (cards, electronic wallets, etc.). However, these kinds of promotions are still limited in Vietnam and do not encourage consumers to use e-payment.

The other consequences including C11, C2, and C9, which are linked from A13, A2 and A9, at 81, 70 and 55, respectively. All linkages in the HVM show that the obstacles can come from both customers (Lack of information on E-payment and its benefits) and external side (No available laws to protect E-payment users or E-payment is not widely- used).

The HVM shows six A-C-V linkages (A11-C4-V1, A2-C2-V2, A13-C11-V2, A13C12-V2, A15-C12-V2, and A9-C9-V3) and the core value of V2 (Safety) linked from 274 occurrences (from C2, C11, C12, at 77, 102, and 95, respectively). Firstly, among the six linkages, A11- C4-V1 is the most noticed linkage with the highest number of occurrences (85, 115). This means customers really care about additional cost and economic benefits/discounts when adopting e-payment as a new payment method. The extra costs prevent them from using e-payment as they impact their personal value of "Economy". For these customers, "Economy" is the underlying reason that resists their willingness to adopt e- payment.

Secondly, there are four A-C-V linkages that connect to the core value of "Safety": A2$\mathrm{C} 2-\mathrm{V} 2$, A13-C11-V2, A13-C13-V2, and A15-C12-V2. The A2-C2-V2 linkage shows that customers do not have a clear understanding of e-payment because of a lack of information about e-payment and its benefits. They feel unsafe when trying a new and unfamiliar payment method, and thus, avoid using it. When equipped with more information about e-payment, they certainly will be confident in using the new service. The following two A13-C11-V2 and A13C13-V2 linkages show another important attribute of E-payment: the information security system. The unsecured security system of E-payment can lead to many bad impacts including the risk of card and account information disclosure (C11) and the risk of losing money (C13). Customers feel unsafe to try new payment methods when they see so many cases of payment fraud on the media due to weaknesses of the bank security system. The last A-C-V linkage leading to the safety value is A15-C12-V2. The current legal framework is inadequate and updated to protect users in case of disputes when they use such a new service as e-payment. The risk of losing money when doing online transactions becomes more real when hackers are stronger and more dangerous. Accordingly, customers decide to stay with traditional payment methods and are reluctant to e-payment. From these four A-C-V linkages, it can be concluded that "Safety" is the core personal value for customers to decide whether to adopt e-payment.

Lastly, in the A9-C9-V3 linkage, customers care about the convenience of using epayment. The fact that not all merchants are equipped with an e-payment system makes it unable for customers to use this method widely. They have no choice but to go back to the traditional cash method, not to mention that many merchants in Vietnam still prefer cash to other forms of payment. No wonder why consumers still feel inconvenient about the new payment service. In summary, "E-payment is not being widely used" links to the underlying personal value of "convenience" that makes customers unwilling to adopt to e-payment. 


\section{Implications and conclusion}

Based on the Means-End chain theory and hard-laddering interview, this study identifies 05 main attributes of E-payment regarded by Vietnamese customers as crucial obstacles from using E-payment. These attributes are A2 "Lack of information about E-payment and its benefits", A13 "Information security system of E-payment is not good", A15 "No available laws to protect E-payment users", A9 "E-payment is not being widely-used", and A11 "Need to pay a transaction fee or no discount for E-payment". Among these 5 attributes, A11 is the one selected by most of the respondents. In particular, A2, A12, and A15 are attributed driving to 03 significant consequences: C2 "Not clearly understand about E-payment", C11 "Risk of disclosing personal information, card and account" and C12 "Risk of losing money", which lead to V2 "Using E-payment is not safe". The HVM of the study shows that Safety is the keyvalue explaining why Vietnamese customer is unwilling to use E-payment.

\section{Implications}

The research findings show 03 important values including Safety, Economy, and Convenience explaining why customers are not willing to use E-payment.

Firstly, the most concerned issue of Safety is that customers are afraid of losing money. To tackle this security issue, building a strong data security system is of importance and a must. IT infrastructure must be strong, the software must be upgraded and up-to-date with technology change. Secondly, another safety solution is developing a risk management plan and business continuity plan. Moreover, E-payment is a high-tech combination of Internet and banking technology. Therefore, it is necessary to improve the knowledge and skillof technical staff to meet the demand for operating the payment systems with high technology and advanced security. The next reason for customers not using e-payment is their unawareness of E-payment benefits and how to use the E-payment system. Therefore, banks and service providers should inform customers more of e-payment. Such information should be conveyed through different channels to approach as many customers as possible and should highlight key benefits for target customers.

In terms of Convenience of E-payment, the payment procedure and other processes must be simplified while still ensuring the security and reliability of the service. Banks and service providers should cooperate to offer clients with standardized e-payment service and platform. In addition, widening the E-payment network to have a high acceptance level by merchants need to be addressed. The government and banks need to expand the ATMs and POS's network in rural areas for inclusive growth. Fintech firms (service providers), on the other hand, need to diversify services by increasing their tie-ups with other service sectors such as utility bill payments, online shopping payments on delivery, education, traditional markets, street shops, etc.

Lastly, regarding the Economy of E-payment, banks, service providers and retailers should have an incentive program or promotion for non-cash transactions, especially in ecommerce and bill payment sectors. For example, in May 2018, Amazon offered to pass along the discounts it gets on credit card fees to other retailers if customers use the online payment 
service (Surane \& Soper, 2018). Another option that was offered by some companies to motivate credit customers to pay sooner to get an early payment discount. By offering free of charge or the minimum fee, it definitely will not limit the usage of e-payment for daily transactions and increase the total number of online transactions significantly.

\section{Research limitations and further research}

Even though all research objectives are addressed, this study also has some limitations. Firstly, the size of 203 qualified samples did not follow the sampling suggested by Gutman (1982) for Association Pattern Technique (APT). Moreover, the matrix format questionnaire used by the study is unpopular and hard for surveyors to answer because it requires a facilitator to clarify how to do the survey. This limits the capability to have more sample sizes from the online survey. Secondly, the scope of this research is limited to Ho Chi Minh City only and is selected by convenience, and thus, its findings cannot be generalized to the whole Vietnamese market.

From the above limitations, the following further research directions are recommended. Firstly, increasing the sample size is necessary to verify the result of this study. Secondly, widening the scope of this research by conducting the survey in different cities will enable researchers to generalize the study to a larger area of Vietnam.

\section{References}

Arango-Arango, C. A., \& Suarez-Ariza, N. F. (2017). Factors impeding the use of electronic payment instruments in emerging economies: The case of Colombia. Journal of Payment Strategy \& System, 10(4), 363-382.

Costa, A. I. A., Dekker, M., \& Jongen, W. M. F. (2004). An overview of means-end theory: Potential application in consumer-oriented food product design. Trends in Food Science \& Technology, 15(7/8), 403-415. doi:10.1016/j.tifs.2004.02.005

Dinh, S. V., Nguyen, V. H., \& Nguyen, N. T. (2018). Cash or cashless? Promoting consumers' adoption of mobile payments in an emerging economy. Strategic Direction, 34(1), 1-4. doi:10.1108/SD-08-2017-0126

Fintechnews. (2017). Vietnam Announces Major Initiative to Become Cashless by 2020. Retrieved August 20, 2018, from http://fintechnews.sg/7986/vietnam/vietnamannounces-major-initiative-become-cashless-2020/

Grunert, K. G., \& Grunert, S. C. (1995). Measuring subjective meaning structures by the laddering method: Theoretical considerations and methodological problems. International Journal of Research in Marketing, 12, 209-225. doi:10.1016/01678116(95)00022-T

Gutman, J. (1982). A means-end chain model based on consumer categorization processes. Journal of Marketing, 46(2), 60-72. doi:10.2307/3203341

Hofstede, F., Audenaert, A., Steenkamp, J.-B. E. M., \& Wedel, M. (1998). An investigation into the association pattern technique as a quantitative approach to measuring means-end 
chains. International Journal of Research in Marketing, 15(1), 37-50. doi:10.1016/S0167-8116(97)00029-3

Hongxia, P., Xianhao, X., \& Weidan, L. (2011). Drivers and barriers in the acceptance of mobile payment in China. Paper presented at the International Conference on E-Business and E-Government, Shanghai, China.

Issahaku, H. (2012). The challenges of implementing electronic payment systems-The case of Ghana's E-zwich payment system. American Journal of Business and Management, l(3), 87-95. doi:10.11634/216796061706131

Kang, H., Kang, M., Yoon, S., \& Kim, D. (2014). A consumer value analysis of mobile internet protocol television based on a means-end chain theory. Service Business, 8(4), 587-613. doi:10.1007/s11628-013-0208-8

Loi, H. V. (2017). 10 things about Vietnam ecommerce you have to experience it yourself. Retrieved September 20, 2018, from https://blog.boxme.asia/blog/vietnam-ecommerceopportunity/

Okifo, J., \& Igbunu, R. (2015). Electronic payment system in Nigeria. Journal of Education and Practice, 6(16), 56-62. Retrieved September 22, 2018, from https://www.iiste.org/Journals/index.php/JEP/article/view/23320

Ram, S., \& Sheth, J. N. (1989). Consumer resistance to innovations: The marketing problem and its solutions. Journal of Consumer Marketing, 6(2), 5-14. doi:10.1108/EUM0000000002542

Reynolds, T. J., \& Gutman, J. (1988). Laddering theory, method, analysis, and interpretation. Journal of Advertising Research, 28(1), 11-31. Retrieved September 23, 2018, from: https://www.researchgate.net/publication/313701310_Laddering_theory_method_analys is_and_interpretation

Sivathanu, B. (2018). Adoption of Internet of Things (IoT) based wearables for elderly healthcare - A behavioural reasoning theory (BRT) approach. Journal of Enabling Technologies, 12(4), 169-185.

Surane, J., \& Soper, S. (2018). Amazon offers retailers discounts to adopt payment system. Retrieved May 10, 2018, from https://www.bloomberg.com/news/articles/2018-0502/amazon-said-to-offer-retailers-discounts-to-adopt-payment-system

Tolman, E.C. (1932). Purposive behavior in animals and men. New York, NY: AppletonCentury.

VietnamBriefing. (2017). Vietnam's payment preferences: Four trends to watch. Retrieved September 25, 2018, from https://www.vietnam-briefing.com/news/vietnams-paymentpreferences-4-trends- watch.html/

VietNamNews. (2017). Bright prospects seen for digital banking. Retrieved September 28, 2018, from https://vietnamnews.vn/economy/350099/bright-prospects-seen-for-digitalbanking.html\#FV2jcr7w5sftUMEV.97

Yassaman, M. (2009). Reasons Barring Customers from Using Internet Banking in Iran: An Integrated Approach Based on Means-End Chains and Segmentation. (Unpublished doctoral dissertation). University of Technology, Iran. 